\title{
CHANGES IN BODY COMPOSITION IN ACUTE RENAL FAILURE ${ }^{1}$
}

\author{
By L. W. BLUEMLE, JR., ${ }^{2}$ H. P. POTTER, and J. R. ELKINTON 3 \\ (From the Chemical Section of the Department of Medicine, University of Pennsylvania, \\ School of Medicine, Philadelphia, Penna.)
}

(Submitted for publication April 9, 1956; accepted June 11, 1956)

To a large degree the therapy of acute renal failure depends on an understanding of biochemical disturbances that result from the temporary $a b-$ sence of renal excretory and homeostatic functions. Important among these disturbances are changes in the volume and composition of body fluids, particularly with respect to electrolyte constituents. While certain manifestations of these changes are frequently recognized on the clinical level, relatively little quantitative data are available from which can be derived a general pattern of body fluid alterations in this disease. One reason for this paucity of information, aside from the limitations of investigative techniques, is the inherent difficulty of performing adequate studies on critically ill patients.

Sirota and Kroop (1) observed in 4 oliguric patients an expansion of inulin space roughly commensurate with estimated positive fluid balance. They postulated that the oliguric phase of acute renal failure is associated with cellular dehydration resulting from a shift of water out of cells, and that hyponatremia may result in part from extracellular dilution and in part from a shift of sodium into cells. The observation by Schwartz, Tomsovic, and Schwartz (2) of greater expansion of inulin space than of $\mathrm{D}_{2} \mathrm{O}$ space in one anuric child would conform with this concept. Iseri, Batchelor, Boyle, and Myers (3) also suggested that the hyponatremia and hypochloremia of oliguria may be due in part to cellular uptake of sodium and shift of water from cells to extracellular fluid.

1 This study was aided by grants from The American Philosophical Society, The National Heart Institute of the U.S.P.H.S. (H-340), and the C. Mahlon Kline Fund of the Department of Medicine, University of Pennsylvania.

$2 \mathrm{~J}$. Allison Scott Fellow of the Department of Research Medicine (1953-55); Markle Scholar in Medical Science 1955-56.

${ }^{3}$ Established Investigator of The American Heart Association.
The role of catabolism in augmenting total body water through water of oxidation and release of preformed water was evaluated by Hamburger and Richet (4), largely by inference from observations made during post-oliguric diuresis. Changes in the volume and distribution of body water were also studied in anuric dogs by Hamburger and Mathé (5), who found close agreement between the expansion of total body water as measured by $\mathrm{D}_{2} \mathrm{O}$ spaces and the amount of water derived from metabolic processes. On the basis of extensive clinical observation and a limited number of isotopic dilution studies, Merrill (6) has enumerated some of the fluid and electrolyte changes frequently seen in prolonged acute renal failure, as follows : 1) an increase in total body water, 2) an increase in total body sodium with a decreasing serum concentration, 3) a decrease in total body potassium with an elevated serum level, and 4) an increased extracellular fluid volume.

The primary purpose of the present study was to obtain more complete information concerning the type and magnitude of changes in volume and electrolyte composition of body fluids in acute renal failure, to assess the roles of catabolic processes and concomitant fluid therapy in their genesis, and to delineate certain therapeutic implications of this information.

\section{EXPERIMENTAL MATERIAL AND METHODS}

Eight patients with acute renal failure were studied by the balance technique on the Metabolic Unit of the Hospital of the University of Pennsylvania. Studies were initiated in 13 patients but were interrupted or invalidated in $\mathbf{5}$ for various reasons. Measurements were made of intake of water, solids, chloride, sodium, potassium, nitrogen, and carbohydrate and fat, and of all output of water, solids, chloride, sodium, potassium, and nitrogen. At the beginning and end of each unit balance period ( 24 to 72 hours) body weight was obtained on a stretcher-scale (7) and blood was drawn for determinations of serum chloride, sodium, potassium, $\mathrm{CO}_{2}$ content, and blood urea nitrogen. Chemical methods of these analyses have been previously described (8). On 
TABLE I

Summary of clinical material

\begin{tabular}{|c|c|c|c|c|c|c|c|c|c|}
\hline Patient & Age & Sex & $\begin{array}{c}\text { Body } \\
\text { surface } \\
\text { area* } \\
\text { (sq. meters) }\end{array}$ & $\begin{array}{l}\text { Apparent cause of acute } \\
\text { renal failure }\end{array}$ & Complicating factors & $\begin{array}{c}\text { Dura- } \\
\text { tion of } \\
\text { oliguria } \\
\text { (days) }\end{array}$ & $\begin{array}{l}\text { Dura- } \\
\text { tion of } \\
\text { study } \\
\text { (days) } \\
\end{array}$ & $\begin{array}{l}\text { Day of } \\
\text { dialysis } \\
\text { (from } \\
\text { onset of } \\
\text { oliguria) }\end{array}$ & Result \\
\hline V.N. & 42 & $\mathbf{F}$ & 1.82 & $\begin{array}{l}\text { Hemolytic reaction to } \\
1000 \mathrm{ml} \text {. incompatible } \\
\text { blood during hyster- } \\
\text { ectomy }\end{array}$ & $\begin{array}{l}\text { Acute parotid abscess } \\
\text { during diuretic phase }\end{array}$ & 12 & 24 & 7 & Recovered \\
\hline E. G. & 41 & $F$ & 1.59 & $\begin{array}{l}\text { Hemolytic reaction to } \\
2000 \text { ml. incompatible } \\
\text { blood during hyster- } \\
\text { ectomy }\end{array}$ & $\begin{array}{l}\text { Pelvic peritonitis, con- } \\
\text { vulsions during diure- } \\
\text { tic phase }\end{array}$ & 12 & 22 & 7 & Recovered \\
\hline B. S. & 26 & $\mathbf{F}$ & 1.55 & Septic abortion & $\begin{array}{l}\text { Peritonitis, pelvic ab- } \\
\text { scess, GI hemorrhage, } \\
\text { chemical pericarditis, } \\
\text { pul. congestion }\end{array}$ & 12 & 15 & 10 & Recovered \\
\hline K. B. & 42 & $F$ & 1.73 & $\begin{array}{l}\text { Hemolytic reaction to } \\
2000 \text { ml. incompatible } \\
\text { blood during cholecys- } \\
\text { tectomy }\end{array}$ & $\begin{array}{l}\text { Convulsions during } \\
\text { diuretic phase }\end{array}$ & 14 & 19 & 8 & Recovered \\
\hline I. T. & 60 & $\mathbf{F}$ & 1.72 & $\begin{array}{l}\text { Hypotension during } \\
\text { facial surgery for car- } \\
\text { cinoma }\end{array}$ & $\begin{array}{l}\text { Hemorrhage from op- } \\
\text { erative site during } \\
\text { diuretic phase }\end{array}$ & 17 & 22 & 8 & Recovered \\
\hline M. G. & 43 & $\mathbf{F}$ & 1.89 & $\begin{array}{l}\text { Hypotension follow- } \\
\text { ing hysterectomy }\end{array}$ & $\begin{array}{l}\text { Pulmonary edema, po- } \\
\text { tassium intoxication }\end{array}$ & 9 & 3 & None & Died \\
\hline F. B. & 58 & $\mathrm{~F}$ & 1.47 & $\begin{array}{l}\text { Hypotension during } \\
\text { cardiac surgery }\end{array}$ & $\begin{array}{l}\text { Shock following dialy- } \\
\text { sis }\end{array}$ & 10 & 12 & 9 & Recovered \\
\hline D. S. & 24 & $\mathrm{~F}$ & 1.74 & $\begin{array}{l}\text { Postpartum shock and } \\
\text { hemolytic reaction to } \\
500 \mathrm{ml} \text {. incompatible } \\
\text { blood }\end{array}$ & $\begin{array}{l}\text { Convulsions during } \\
\text { diuretic phase }\end{array}$ & 10 & 14 & 9 & Recovered \\
\hline
\end{tabular}

* Surface area in sq. meters $=\mathrm{Wt}^{0.025} \times \mathrm{Ht}^{0.726} \times 0.007184$ (after DuBois and DuBois [15]).

completion of each study the observed data were analyzed for each unit balance period and recorded for the sake of convenience as average values per 24 hours for each of the following three phases: I) the oliguric phase (urine volume less than $400 \mathrm{ml}$. per 24 hours), II) the early diuretic phase (urine volume $400 \mathrm{ml}$. per 24 hours to maximal diuresis), and III) late diuretic phase (maximal diuresis to end of study). In all except one case (M. G.) balance studies were continued until the patient was ambulatory and was receiving no special therapy. It should be clearly pointed out that balance studies were not inititated at the onset of oliguria in any of these patients, the average interval being 8.4 days, the shortest 5 days, between onset of oliguria and beginning of studies. Hence the cumulative data relating to Phase I should not be considered representative of metabolic changes during the entire oliguric period.

Brief clinical summaries of each case are presented in Table I. All patients were transferred from other hospitals in either the latter part of the oliguric phase or the early diuretic phase. Duration of study ranged from 3 to 24 days (average 16.4 days). Four patients were studied during Phases I, II, and III; two during only
Phases II and III; one during only Phases I and II, and one during only Phase I. All patients were critically ill at the time of transfer, and all except one (M. G.) were treated by extracorporeal hemodialysis prior to initiation of balance studies.* No attempt was made to determine the effect of dialysis on subsequent fluid and electrolyte balance; however, the predominant effect as judged by improvement in serum electrolyte pattern and, in some cases, loss of excess body water (by ultrafiltration) was to compensate partially for the fluid and electrolyte disturbances which had occurred up to that time.

Therapy prior to transfer to our hospital varied considerably from patient to patient. In almost all cases little attempt had been made to restrict fluid intake during the early days of oliguria ; in 3 patients (B. S., I. T., and M. G.) signs of overhydration were evident on admission. Fluid therapy during this study, presented as average intake figures in Table II, followed generally accepted principles of attempting to prevent or correct the more

4 In one case (K. B.) dialysis was performed on the third day of study, and this day was omitted from the calculations. 
serious fluid and electrolyte disturbances as judged by clinical observations and serum studies. Balance data were not used as the primary criteria for judging subsequent fluid therapy. During the oliguric phase intake was limited to an average of $1,000 \mathrm{ml}$. per day, or roughly $700 \mathrm{ml}$. plus previous 24-hour measured water loss, except in one case (M. G.) where pulmonary edema necessitated more drastic fluid restriction. Electrolyte intake was also limited during this phase because of minimal output. Both water and electrolyte intake were increased during Phases II and III to compensate for increasing urinary losses.

\section{CALCULATIONS}

Changes in the composition of the body and in certain constituents of the body fluids may be calculated from the data obtained by the balance technique as described above. Although most of these derivations have been in use for many years, the equations which were used in this study are presented here in order that our analysis may be clearly understood. The validity of the data so derived is taken up subsequently under Discussion.

\section{Metabolic mixture}

Carbohydrate burned (C) was assumed to be equivalent to the carbohydrate administered.

Protein burned (P) in grams was calculated from the nitrogen excretion in the urine $\left(U_{N}\right)$ in grams corrected for changes in the amount of the urea nitrogen in the body fluids $(\triangle B U N)$ in grams:

$$
\mathrm{P}=6.25 \times\left(\mathrm{UV}_{\mathrm{N}}+\Delta \mathrm{BUN}\right) .
$$

This latter correction, a proportionately large one in the severely oliguric patient, was made by multiplying the change in concentration of blood urea nitrogen $(\Delta[B U N])$, in grams per liter, by an assumed volume for total body water $(\mathrm{W})$ in liters :

$$
\Delta B U N=\Delta[B U N] \times W .
$$

Since change in the last factor, $W$, is one objective of the calculation, a series of approximations beginning with a total body water assumed to be 73.2 per cent of the lean body mass at the end of the study, permits a reasonable calculation of this portion of the protein burned.

Fat burned (F) was calculated from the insensible weight loss (IL) and the carbohydrate and protein burned, according to the formula of Lavietes (9) :

$$
\mathrm{F}=(\mathrm{IL}-2.12 \mathrm{C}-1.69 \mathrm{P}) / 3.79 \text {, }
$$

where

$$
\mathrm{IL}=(\mathrm{Wt} \text {. intake }-\mathrm{Wt} \text {. output })-\Delta \mathrm{Wt} .
$$

\section{Change in body composition}

Change in body fat $(\triangle \mathrm{BF})$ was taken as the difference between the exogenous fat given ( $F_{0 x}$ ) and the fat burned (F) :

$$
\Delta \mathrm{BF}=\mathrm{F}_{\mathrm{ex}}-\mathrm{F} \text {. }
$$

Change in total body water $(\Delta \mathrm{W})$ was calculated from the change in weight $(\Delta \mathrm{Wt})$ corrected for the balance of solids ( Sexcreta $-S_{\text {Ingesta }}$ ) and the metabolic mixture (10):

$$
\Delta \mathrm{W}=\Delta \mathrm{Wt}+\left(\mathrm{S}_{\bullet}-\mathrm{S}_{1}\right)+(\mathrm{C}+\mathrm{F}+0.54 \mathrm{P}) .
$$

Change in total body solids ( $\triangle \mathrm{BS})$ was taken as:

$$
\Delta \mathrm{BS}=\Delta \mathrm{Wt}-(\Delta \mathrm{BF}+\Delta \mathrm{W}) \text {. }
$$

Change in lean body mass ( $\triangle \mathrm{LBM}$ ) was obtained as :

$$
\begin{aligned}
\Delta \mathrm{LBM} & =\Delta \mathrm{Wt}-\Delta \mathrm{BF} \text { or } \\
& =\Delta \mathrm{W}+\Delta \mathrm{BS} .
\end{aligned}
$$

In addition, absolute amounts of the principal body components were estimated in each patient at the end of the study when the body constituents presumably had returned to or toward normal proportions. Lean body mass (LBM) was calculated in all but one case (M. G.) from the excretion rate of creatinine $\left(U V_{c r}\right)$ during the last 2 or 3 days (when the plasma creatinine had fallen to essentially normal levels), by the formula of Miller and Blyth (11) :

$$
\mathrm{LBM}=20.97+0.5161 \mathrm{UV}_{\mathrm{cr}} \text {, }
$$

where $U_{\mathrm{cr}}$ is the excretion rate of creatinine in milligrams per hour, corrected for any change in plasma level (in the same manner as $U V_{N}$ is corrected in Equation 2 above). Given the estimated lean body mass, total body fat (BF), total body water (W), and total body solids (BS) are calculated as :

$$
\begin{gathered}
B F=W T-L B M, \\
W=0.732 L B M, \\
B S=L B M-W .
\end{gathered}
$$

Given these absolute values, changes in total body fat, water, and solids were readily calculated backward in time from the end of the study by using the values for changes derived in Equations 5, 6, and 7 above.

Change in extracellular fiuid volume $\left(\Delta \mathrm{E}_{01}\right)$, as equated with the chloride space, was calculated from the chloride balance in the usual manner (12) and change in intracellular fluid $(\Delta \mathrm{I})$ was taken as the difference between $\Delta \mathrm{W}$ and $\Delta \mathrm{E}_{\mathrm{cl}}$. For purposes of calculation of percentage changes the total extracellular water at the end of the study was assumed to be 22.5 per cent of the lean body mass.

\section{Electrolyte exchanges}

Changes in extracellular sodium and potassium $(\Delta \mathrm{Na}$ and $\Delta \mathrm{K}_{\mathbf{m}}$ ) and in intracellular sodium and potassium $\left(\Delta \mathrm{Na}_{1}\right.$ and $\Delta \mathrm{K}_{\mathrm{I}}$ ) were calculated on the basis of the chloride space in the usual manner as described in Equations 20 to 23 inclusive in Elkinton and Danowski (13). Transfers of intracellular potassium in excess of nitrogen $\left(\Delta \mathrm{K}_{1}^{\prime}\right)$ were calculated on the assumption of a normal $\mathrm{K}: \mathrm{N}$ ratio of $3.0 \mathrm{mEq}$. to $1 \mathrm{gm}$. Electrolyte losses through sweat were not included in the calculations, this loss being considered insignificant since the patients were kept in air-conditioned rooms. 
CHANGES IN BODY COMPOSITION IN ACUTE RENAL FAILURE

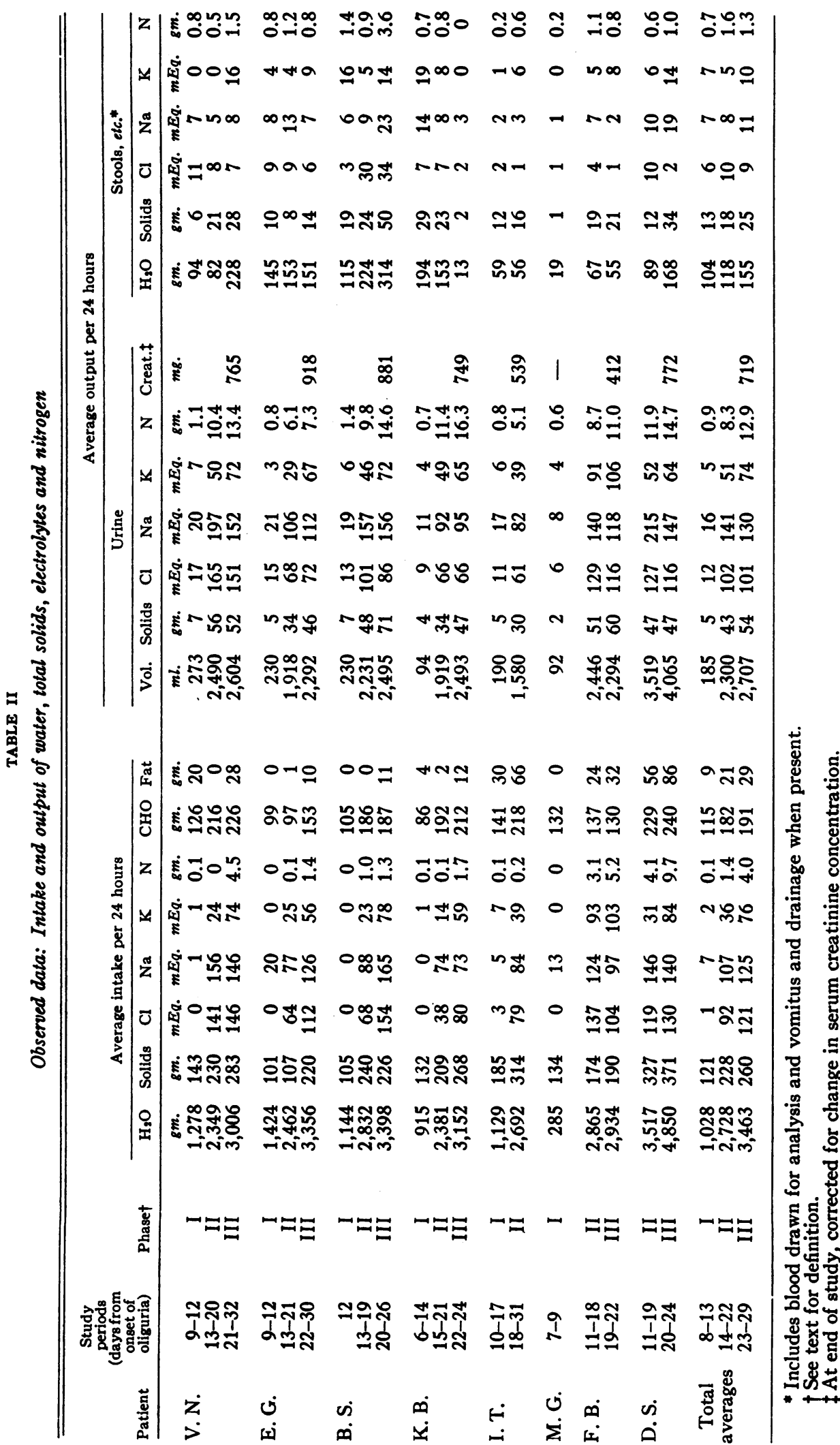


TABLE III

Observed data: body weights, total balances of electrolytes and nitrogen, concentrations of electrolytes in serum and of blood urea nitrogen

\begin{tabular}{|c|c|c|c|c|c|c|c|c|c|c|c|}
\hline \multirow[b]{2}{*}{ Patient } & \multirow{2}{*}{$\begin{array}{l}\text { Day from } \\
\text { onset of } \\
\text { oliguria }\end{array}$} & \multicolumn{4}{|c|}{ Total balance* } & \multirow{2}{*}{$\begin{array}{c}\text { Body } \\
\text { weight }\end{array}$} & \multicolumn{4}{|c|}{ Serum concentration } & \multirow{2}{*}{$\begin{array}{c}\text { Blood } \\
\text { urea } \\
\text { nitrogen }\end{array}$} \\
\hline & & $\mathrm{Cl}$ & $\mathrm{Na}$ & $\mathbf{K}$ & $\mathrm{N}$ & & $\mathrm{Cl}$ & $\mathrm{Na}$ & $\mathbf{K}$ & $\mathrm{CO}_{2}$ & \\
\hline V. N. & $\begin{array}{r}8 \\
12 \\
20 \\
32\end{array}$ & $\begin{array}{l}m E q . \\
-109 \\
-256 \\
-133\end{array}$ & $\begin{array}{l}m E q . \\
-106 \\
-374 \\
-177\end{array}$ & $\begin{array}{l}m E q . \\
-22 \\
-213 \\
-156\end{array}$ & $\begin{array}{c}g m . \\
-\quad 7.5 \\
-87.4 \\
-124.8\end{array}$ & $\begin{array}{c}\text { kg. } \\
79.43 \\
79.08 \\
72.48 \\
68.50\end{array}$ & $\begin{array}{c}m E q . \\
\text { per } L . \\
97 \\
92 \\
91 \\
100\end{array}$ & $\begin{array}{c}m E q . \\
\text { per } L . \\
139 \\
133 \\
138 \\
139\end{array}$ & $\begin{array}{r}m E q . \\
\operatorname{per} L . \\
5.1 \\
5.2 \\
4.0 \\
4.0\end{array}$ & $\begin{array}{c}m M . \\
\operatorname{per} L . \\
28.7 \\
21.8 \\
25.0 \\
31.0\end{array}$ & $\begin{array}{c}m g . \text { per } \\
100 \mathrm{ml} . \\
81 \\
118 \\
148 \\
11\end{array}$ \\
\hline E. G. & $\begin{array}{r}8 \\
12 \\
21 \\
30\end{array}$ & $\begin{array}{r}-92 \\
-119 \\
+309\end{array}$ & $\begin{array}{l}-32 \\
-386 \\
+66\end{array}$ & $\begin{array}{l}-25 \\
-73 \\
-178\end{array}$ & $\begin{array}{r}-6.3 \\
-\quad 64.4 \\
-\quad 59.9\end{array}$ & $\begin{array}{l}61.96 \\
62.21 \\
55.04 \\
53.76\end{array}$ & $\begin{array}{r}88 \\
77 \\
87 \\
103\end{array}$ & $\begin{array}{l}133 \\
128 \\
136 \\
141\end{array}$ & $\begin{array}{l}3.9 \\
3.9 \\
4.9 \\
4.8\end{array}$ & $\begin{array}{l}30.2 \\
27.6 \\
25.5 \\
21.7\end{array}$ & $\begin{array}{r}66 \\
114 \\
82 \\
15\end{array}$ \\
\hline B. S. & $\begin{array}{l}11 \\
12 \\
19 \\
26\end{array}$ & $\begin{array}{l}-16 \\
-440 \\
+232\end{array}$ & $\begin{array}{l}-25 \\
-550 \\
-100\end{array}$ & $\begin{array}{l}-22 \\
-203 \\
-56\end{array}$ & $\begin{array}{l}2.8 \\
-\quad 68.2 \\
-118.9\end{array}$ & $\begin{array}{l}\mathbf{5 9 . 5 0} \\
\mathbf{5 9 . 4 7} \\
\mathbf{5 5 . 0 4} \\
\mathbf{5 1 . 6 6}\end{array}$ & $\begin{array}{r}88 \\
76 \\
105\end{array}$ & $\begin{array}{l}138 \\
131 \\
140\end{array}$ & $\begin{array}{l}4.8 \\
3.5 \\
4.0\end{array}$ & $\begin{array}{l}24.6 \\
25.4 \\
25.8\end{array}$ & $\begin{array}{r}122 \\
142 \\
180 \\
33\end{array}$ \\
\hline K. B. & $\begin{array}{r}5 \\
14 \\
21 \\
24\end{array}$ & $\begin{array}{l}-124 \\
-247 \\
+\quad 39\end{array}$ & $\begin{array}{l}-196 \\
-180 \\
-72\end{array}$ & $\begin{array}{l}-170 \\
-298 \\
-\quad 18\end{array}$ & $\begin{array}{l}-10.4 \\
-84.4 \\
-43.9\end{array}$ & $\begin{array}{l}63.70 \\
60.01 \\
57.14 \\
57.03\end{array}$ & $\begin{array}{l}93 \\
91 \\
91 \\
90\end{array}$ & $\begin{array}{l}134 \\
136 \\
136 \\
135\end{array}$ & $\begin{array}{l}4.7 \\
5.4 \\
3.7 \\
3.8\end{array}$ & $\begin{array}{l}17.5 \\
14.9 \\
30.0 \\
29.3\end{array}$ & $\begin{array}{r}120 \\
175 \\
116 \\
70\end{array}$ \\
\hline I. $T$. & $\begin{array}{r}9 \\
17 \\
31\end{array}$ & $\begin{array}{l}-81 \\
+238\end{array}$ & $\begin{array}{l}-118 \\
-16\end{array}$ & $\begin{array}{l}+3 \\
-90\end{array}$ & $\begin{array}{r}7.5 \\
-77.4\end{array}$ & $\begin{array}{l}68.42 \\
66.84 \\
62.97\end{array}$ & $\begin{array}{r}100 \\
94 \\
99\end{array}$ & $\begin{array}{l}146 \\
141 \\
137\end{array}$ & $\begin{array}{l}5.6 \\
6.3 \\
4.3\end{array}$ & $\begin{array}{l}28.3 \\
20.5 \\
26.4\end{array}$ & $\begin{array}{r}36 \\
140 \\
34\end{array}$ \\
\hline M. G. & $\begin{array}{l}6 \\
9\end{array}$ & -21 & +15 & -11 & -2.4 & $\begin{array}{l}79.90 \\
77.48\end{array}$ & $\begin{array}{l}87 \\
91\end{array}$ & $\begin{array}{l}134 \\
139\end{array}$ & $\begin{array}{r}6.8 \\
10.8\end{array}$ & $\begin{array}{l}19.5 \\
10.8\end{array}$ & $\begin{array}{l}132 \\
248\end{array}$ \\
\hline F. B. & $\begin{array}{l}10 \\
18 \\
22\end{array}$ & $\begin{array}{l}+32 \\
-53\end{array}$ & $\begin{array}{l}-183 \\
-89\end{array}$ & $\begin{array}{l}-29 \\
-40\end{array}$ & $\begin{array}{r}-53.3 \\
-26.6\end{array}$ & $\begin{array}{l}45.10 \\
39.60 \\
39.06\end{array}$ & $\begin{array}{r}85 \\
104 \\
102\end{array}$ & $\begin{array}{l}131 \\
143 \\
138\end{array}$ & $\begin{array}{l}4.2 \\
4.0 \\
4.0\end{array}$ & $\begin{array}{l}25.5 \\
25.8 \\
25.6\end{array}$ & $\begin{array}{l}80 \\
72 \\
39\end{array}$ \\
\hline D. S. & $\begin{array}{l}10 \\
19 \\
24\end{array}$ & $\begin{array}{l}-162 \\
+63\end{array}$ & $\begin{array}{l}-708 \\
-135\end{array}$ & $\begin{array}{l}-253 \\
+31\end{array}$ & $\begin{array}{l}-75.2 \\
-30.2\end{array}$ & $\begin{array}{l}67.13 \\
59.32 \\
57.78\end{array}$ & $\begin{array}{r}84 \\
103 \\
109\end{array}$ & $\begin{array}{l}134 \\
141 \\
140\end{array}$ & $\begin{array}{l}6.3 \\
3.7 \\
4.2\end{array}$ & $\begin{array}{l}26.5 \\
18.9 \\
18.9\end{array}$ & $\begin{array}{r}112 \\
72 \\
30\end{array}$ \\
\hline
\end{tabular}

* Total balance data for each phase are recorded at the end of each phase, indicated in time as the day from onset of oliguria.

\section{Water exchange}

The individual factors which determined the net water exchange (and hence $\Delta \mathrm{W}$ as calculated in Equation 6 above) were calculated as follows :

"Sensible" water loss (SL) was measured as the sum of water in urine, feces, vomitus, and blood drawn for analysis. "Insensible" water loss (IW) in these patients included water vaporized from lungs and skin, and was taken as equivalent to 91 per cent of the insensible weight loss (IL) as measured (Equation 4) (9).

Available water included exogenous water administered $\left(\mathrm{H}_{2} \mathrm{O}_{\text {ex }}\right)$ plus endogenous water from oxidation $\left(\mathrm{H}_{2} \mathrm{O}_{\text {ox }}\right)$ of the metabolic mixture and preformed water $\left(\mathrm{H}_{2} \mathrm{O}_{\mathrm{pe}}\right)$ released in the catabolism of tissues. Water of oxidation was calculated (14) as :

$$
\mathrm{H}_{2} \mathrm{O}_{\text {ox }}=0.6 \mathrm{C}+1.07 \mathrm{~F}+0.43 \mathrm{P}
$$

and preformed water (pre-existing intracellular water released with cellular catabolism) as :

$$
\mathrm{H}_{2} \mathrm{O}_{\mathrm{pt}}=18.75 \mathrm{bs}^{\prime} \text {, }
$$

where $b_{N}{ }^{\prime}$ is the balance of nitrogen corrected for the change in body fluid urea nitrogen (Equation 2) and the factor 18.75 is $6.25 \times 3.0$ (it being assumed that there are approximately 3 parts of water to 1 part of protein in muscle, the bulk tissue of the body).

The amount of exogenous water in excess of measured "sensible" water loss, which is required to maintain a normal ratio of body water to total body solids, $\left(\mathrm{H}_{2} \mathrm{O}_{e x^{\prime}}\right)$, is the difference between the insensible water loss and the amount of water available endogenously:

$$
\mathrm{H}_{2} \mathrm{O}_{\text {ex }}{ }^{\prime}=\mathrm{IW}-\left(\mathrm{H}_{2} \mathrm{O}_{\text {ox }}+\mathrm{H}_{2} \mathrm{O}_{\mathrm{p} \mathrm{f}}\right) \text {. }
$$

\section{RESULTS}

Observed data are recorded in Tables II and III. Chloride balance was uniformly negative during the latter part of oliguria, as was sodium

5 Complete protocol of representative case is presented in Table VI (Appendix). 
balance except in case M. G. In Phases II and III chloride balance was less negative or more positive than sodium balance, a reflection of excessive urinary sodium loss during diuresis, since generally sodium intake exceeded chloride intake. Potassium and nitrogen balances were predominantly negative. Body weight fell an average of 0.27 kilogram per day during Phase I, 0.62 kilogram per day during Phase II, and 0.26 kilogram per day during Phase III. The increase in weight loss during early diuresis correlates well with increasing loss of total body water at this time (see below).

Derived data are presented in Table IV. For the sake of brevity these values are recorded as daily averages and standard deviations for each phase, all individual values having been corrected to a standard body surface area of 1.68 sq. meters (the mean for this group of patients). ${ }^{\circ}$

\section{A. Metabolic mixture}

Caloric expenditure averaged approximately 2,500 calories per day with little variation from patient to patient or from phase to phase. The average amounts of protein, carbohydrate, and fat burned as calculated by the methods described are enumerated. During Phase I fat constituted the major portion of the metabolic mixture and this represents primarily endogenous fat, since little exogenous fat was given. The amount of fat catabolized decreased progressively during Phases

${ }^{6}$ Body surface area in sq. meters $=\mathrm{Wt}^{0.405} \times \mathrm{Ht}^{0.725} \times$ 0.007184 (after DuBois and DuBois [15]).

TABLE IV

Derived data: Mean* daily values for metabolic mixture, changes in body composition and exchanges of electrolytes and water

\begin{tabular}{|c|c|c|c|c|c|c|c|}
\hline & & \multicolumn{6}{|c|}{ Phaset } \\
\hline & & \multicolumn{2}{|c|}{ I } & \multicolumn{2}{|c|}{ II } & \multicolumn{2}{|c|}{ III } \\
\hline & & mean & s.d. & mean & s.d. & mean & s.d. \\
\hline \multicolumn{8}{|l|}{ A. Metabolic mixture } \\
\hline $\begin{array}{l}\text { CHO burned } \\
\text { Protein burned } \\
\text { Fat burned } \\
\text { Caloric expenditure }\end{array}$ & $\begin{array}{l}\mathrm{gm} . / 24 \mathrm{hr} . \\
\mathrm{gm} . / 24 \mathrm{hr} . \\
\mathrm{gm} . / 24 \mathrm{hr} \text {. } \\
\text { cal./24 hr. }\end{array}$ & $\begin{array}{r}113 \\
42 \\
201 \\
2,405\end{array}$ & $\begin{array}{l} \pm 18 \\
\pm 19 \\
\pm 32 \\
\pm 150\end{array}$ & $\begin{array}{r}183 \\
52 \\
177 \\
2,610\end{array}$ & $\begin{array}{l} \pm 42 \\
\pm 21 \\
\pm 103 \\
\pm 402\end{array}$ & $\begin{array}{r}194 \\
59 \\
140 \\
2,339\end{array}$ & $\begin{array}{l} \pm 28 \\
\pm 15 \\
\pm 66 \\
\pm 263\end{array}$ \\
\hline \multicolumn{8}{|l|}{ B. Changes in body composition } \\
\hline $\begin{array}{l}\Delta F_{a t} \\
\Delta W \\
\Delta E_{\mathrm{Cl}} \\
\Delta I \\
\Delta \text { Solids } \\
\Delta \text { LBM }\end{array}$ & $\begin{array}{l}\mathrm{gm} . / 24 \mathrm{hr} . \\
\mathrm{ml} . / 24 \mathrm{hr} \text {. } \\
\mathrm{ml} . / 24 \mathrm{hr} . \\
\mathrm{ml} . / 24 \mathrm{hr} . \\
\mathrm{gm} . / 24 \mathrm{hr} . \\
\mathrm{gm} . / 24 \mathrm{hr} .\end{array}$ & $\begin{array}{l}-195 \\
-\quad 54 \\
=70 \\
+16 \\
-30 \\
-83\end{array}$ & $\begin{array}{l} \pm 49 \\
\pm 327 \\
\pm 101 \\
\pm 261 \\
\pm 17 \\
\pm 330\end{array}$ & $\begin{array}{l}-156 \\
-435 \\
-242 \\
-193 \\
-64 \\
-499\end{array}$ & $\begin{array}{l} \pm 89 \\
\pm 241 \\
\pm 197 \\
\pm 193 \\
\pm 24 \\
\pm 272\end{array}$ & $\begin{array}{l}-110 \\
-\quad 59 \\
-33 \\
-26 \\
=76 \\
-135\end{array}$ & $\begin{array}{l} \pm 90 \\
\pm 145 \\
\pm 119 \\
\pm 104 \\
\pm 36 \\
\pm 169\end{array}$ \\
\hline \multicolumn{8}{|l|}{ C. Electrolyte exchanges } \\
\hline $\begin{array}{l}\Delta \mathrm{Cl} \\
\Delta \mathrm{Na}_{\mathrm{E}} \\
\Delta \mathrm{Na}_{\mathbf{I}} \\
\Delta \mathrm{K}_{\mathrm{E}} \\
\Delta \mathrm{K}_{\mathrm{I}} \\
\Delta \mathrm{K}_{\mathrm{I}^{\prime}}\end{array}$ & $\begin{array}{l}\text { mEq./24 hr. } \\
\text { mEq./24 hr. } \\
\text { mEq./24 hr. } \\
\text { mEq. } / 24 \mathrm{hr} \text {. } \\
\text { mEq. } / 24 \mathrm{hr} . \\
\text { mEq. } / 24 \mathrm{hr} .\end{array}$ & $\begin{array}{l}-16 \\
-\quad 15 \\
+\quad 1 \\
+\quad 4 \\
+\quad 12 \\
+11\end{array}$ & $\begin{array}{lr} \pm & 2 \\
\pm & 10 \\
\pm & 9 \\
\pm & 7 \\
\pm & 12 \\
\pm & 8\end{array}$ & $\begin{array}{l}-20 \\
-\quad 30 \\
-\quad 13 \\
-\quad 2 \\
=\quad 18 \\
+\quad 5\end{array}$ & 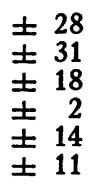 & $\begin{array}{l}+12 \\
-\quad 4 \\
-12 \\
\pm \quad 0 \\
-\quad 9 \\
+12\end{array}$ & $\begin{array}{l} \pm 22 \\
\pm 17 \\
\pm 17 \\
\pm 1 \\
\pm 10 \\
\pm 12\end{array}$ \\
\hline \multicolumn{8}{|l|}{ D. Water exchanges } \\
\hline $\begin{array}{l}\text { Exogenous intake }\left(\mathrm{H}_{2} \mathrm{O}_{\text {IN }}\right) \\
\text { Water of oxidation }\left(\mathrm{H}_{2} \mathrm{O}_{\text {ox }}\right) \\
\text { Endogenous preformed }\left(\mathrm{H}_{2} \mathrm{O}_{\mathrm{pf}}\right) \\
\text { Insensible loss (IW) } \\
\text { Sensible loss (SL) } \\
\text { Water required in excess of SL }\end{array}$ & $\begin{array}{l}\mathrm{ml} . / 24 \mathrm{hr} . \\
\mathrm{ml} . / 24 \mathrm{hr} . \\
\mathrm{ml} . / 24 \mathrm{hr} . \\
\mathrm{ml} . / 24 \mathrm{hr} . \\
\mathrm{ml} . / 24 \mathrm{hr} . \\
\mathrm{ml} . / 24 \mathrm{hr} .\end{array}$ & $\begin{array}{r}1,028 \\
303 \\
124 \\
981 \\
296 \\
554\end{array}$ & $\begin{array}{l} \pm 441 \\
\pm 30 \\
\pm 75 \\
\pm 141 \\
\pm 113 \\
\pm 104\end{array}$ & $\begin{array}{r}2,780 \\
332 \\
132 \\
1,042 \\
2,452 \\
587\end{array}$ & $\begin{array}{l} \pm 470 \\
\pm 96 \\
\pm 57 \\
\pm 278 \\
\pm 623 \\
\pm 226\end{array}$ & $\begin{array}{r}3,530 \\
291 \\
109 \\
954 \\
3,056 \\
554\end{array}$ & $\begin{array}{l} \pm 646 \\
\pm 67 \\
\pm 45 \\
\pm 206 \\
\pm 579 \\
\pm 156\end{array}$ \\
\hline
\end{tabular}
$\left(\mathrm{IW}-\mathrm{H}_{2} \mathrm{O}_{0 x}-\mathrm{H}_{2} \mathrm{O}_{\mathrm{pt}}\right)$

* Mean of individual values for all patients in each phase corrected to standard body surface area of 1.68 sq. meters (the average body surface area for the group).

† Six patients studied during Phase I, 7 during Phase II, and 6 during Phase III.

$\ddagger$ Values refer only to latter part of oliguric phase (average 5 days) since studies were not begun at onset of oliguria. 
II and III, possibly a reflection of decreasing stores of body fat and/or of increasing exogenous caloric intake. The amount of protein burned averaged approximately 50 grams per day in this series, and the amount of carbohydrate burned was assumed to be equal to that given. (Significant glycosuria was absent in all patients.)

\section{B. Changes in body composition}

The derived data from Table IV (B) are presented as average cumulative changes in Figure 1, the duration of each phase being the mean for the group. Expressed in this manner, 15 per cent of initial body fat, 14 per cent of initial body water, and 12 per cent of initial body solids were lost during the entire period of study (mean 21 days). Extracellular water was diminished by 25 per cent, and intracellular water by 9 per cent. Expressed in different terms, of the mean loss of body weight 34 per cent represented loss of fat, 52 per cent loss of water, and 14 per cent loss of solids.

Fat was estimated to constitute a relatively large portion of total body weight in these patients, all but one of whom were clinically obese. Body fat was depleted at steadily decreasing rates throughout the period of study. If the rate of endogenous fat catabolism during the early part of Phase I, before studies were initiated, can be assumed to be roughly equal to that calculated during the latter part of this phase (195 grams per day), then mean fat loss during the entire period of oliguria could be adjusted upward to 13 per cent of total fat stores and to 23 per cent during all three phases.

Lean body mass (water and solids) was diminished by an average of 26 per cent during the entire period of study, accounting for approximately 66 per cent of the total weight loss.

Changes in volume of total body water, extracellular and intracellular water were variable,

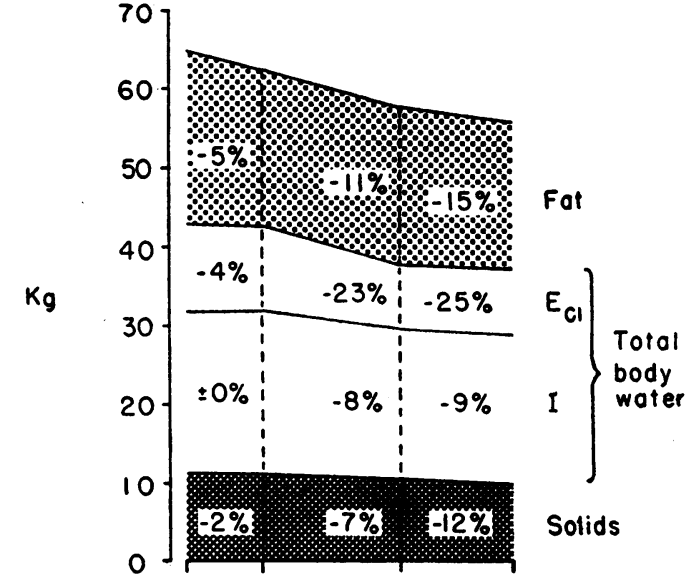

\begin{tabular}{l|c|ccc} 
Doy from onset & 8 & 13 & 22 & 29 \\
Phose & - I & $\underset{\substack{\text { Eorly } \\
\text { Oliguric }}}{\text { Lote }} \mid$
\end{tabular}

Fig. 1. Changes in Body Composition in Acute Renal FaILURe

Mean cumulative changes in 8 patients of body weight, fat, total water, chloride space $\left(E_{0_{1}}\right)$, non-chloride space (I), and solids, based on the values presented in Table IV (B), and a mean initial body weight of $65 \mathrm{~kg}$.

particularly during Phase I. Mean values, however, indicated a depletion of total body water during each phase, the rate of loss being approximately eight times greater in Phase II $(-435 \mathrm{ml}$. per day) than in Phases I and III ( -54 and - $59 \mathrm{ml}$. per day, respectively). Also during Phase II more than 50 per cent of the total water loss came from the chloride space, representing a mean reduction of 19 per cent of this space compared to a mean reduction of 8 per cent of the nonchloride space.

Body solids decreased at slow, gradually increasing rates $(30,64$, and 76 grams per day in Phases I, II, and III, respectively). These

TABLE V

Derived data: Estimated mean body composition at start of study and end of Phases $I, I I$, and III, expressed as percentages of total body weight and of lean body mass*

\begin{tabular}{|c|c|c|c|c|c|c|c|c|c|}
\hline \multirow[b]{2}{*}{ Time } & \multirow{2}{*}{$\begin{array}{c}\text { Fat } \\
\% \text { wt. }\end{array}$} & \multicolumn{2}{|c|}{ Water } & \multicolumn{2}{|c|}{$E_{c 1}$} & \multicolumn{2}{|c|}{ I } & \multicolumn{2}{|c|}{ Solids } \\
\hline & & $\% w t$ & $\% L B M$ & \% wt. & $\% L B M$ & \% wt. & $\% L B M$ & $\%$ wt. & $\%$ LBM \\
\hline $\begin{array}{l}\text { Start of study } \\
\text { End Phase I } \\
\text { End Phase II } \\
\text { End Phase III }\end{array}$ & $\begin{array}{l}34.8 \\
34.0 \\
35.1 \\
34.7\end{array}$ & $\begin{array}{l}48.2 \\
48.8 \\
47.1 \\
47.8\end{array}$ & $\begin{array}{l}73.8 \\
74.0 \\
72.5 \\
73.2\end{array}$ & $\begin{array}{l}16.9 \\
16.9 \\
14.8 \\
14.7\end{array}$ & $\begin{array}{l}25.9 \\
25.5 \\
22.7 \\
22.5\end{array}$ & $\begin{array}{l}31.3 \\
32.0 \\
32.3 \\
33.1\end{array}$ & $\begin{array}{l}47.9 \\
48.5 \\
49.8 \\
50.7\end{array}$ & $\begin{array}{l}17.0 \\
17.2 \\
17.8 \\
17.5\end{array}$ & $\begin{array}{l}26.2 \\
26.0 \\
27.5 \\
26.8\end{array}$ \\
\hline
\end{tabular}

* For deviation see Calculations. 
changes, calculated indirectly from changes in body weight minus changes in body fat and water, were in fair agreement with direct measurements of solids lost in urine and feces, averaging 18, 61, and 79 grams per day in successive phases.

While the overall average losses of total body fat, water, and solids were appreciable, relatively little change occurred in body composition in terms of the ratio of each compartment to total body weight (Table V). Thus it would appear that the total decrements of fat, water, and solids were roughly proportional to their respective proportions of the total body weight. This generalization does not hold, however, during the early diuretic phase (Phase II) when total body water loss, particularly extracellular fluid loss, was disproportionately great.

\section{Electrolyte changes}

The derived data from Table IV (C) are presented as average cumulative balances in Figure

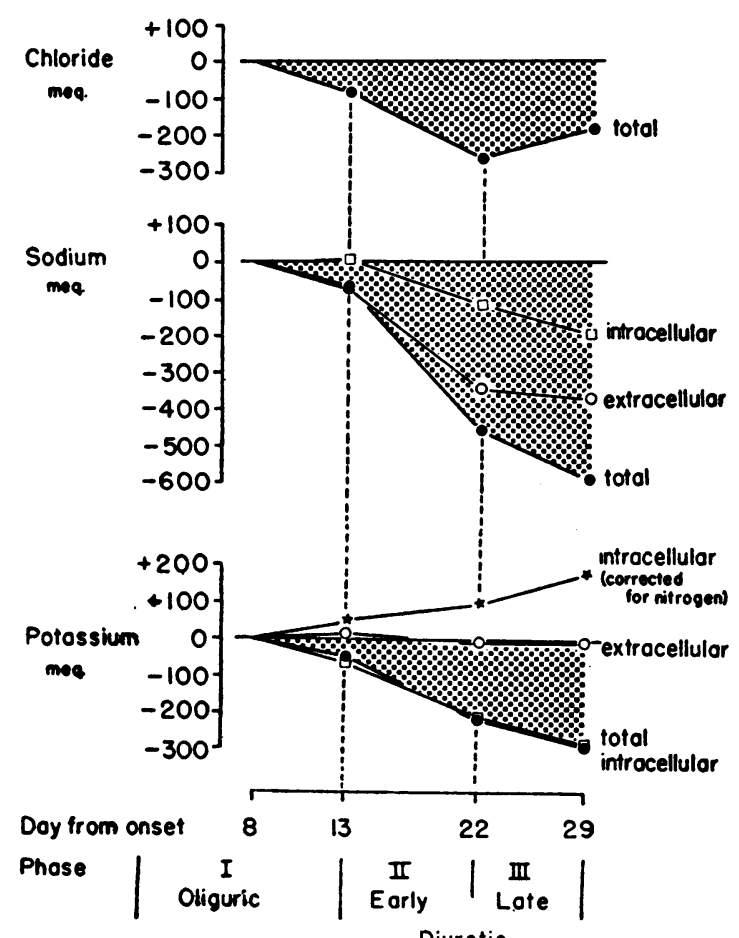

Fig. 2. External Balances and Internal Transfers of Electrolytes in Acute Renal Failure

Mean cumulative balance of chloride, sodium, and potassium, and mean cumulative changes in intracellular and extracellular sodium and potassium, based on values presented in Table IV (C).
2. Significant mean negative balances of chloride were observed in the first two phases, and of sodium in all three phases. Maximal rates of negative sodium and chloride balance coincided with maximal rates of negative water balance, during the early diuretic phase. Total average negative sodium balance ( $-569 \mathrm{mEq}$.) exceeded total average negative chloride balance ( $-181 \mathrm{mEq}$.) by $388 \mathrm{mEq}$. Total average potassium balance was $-288 \mathrm{mEq}$. Maximum negative daily balance of all three electrolytes occurred during Phase II.

Cumulative chloride balances were: -82 , -264 , and - $181 \mathrm{mEq}$. in Phases I, II, and III, respectively. Average daily chloride balances in each of these phases were: $-16.3( \pm 2.4)$, 20.3 ( \pm 27.7$)$, and $+11.9( \pm 21.8) \mathrm{mEq}$., respectively. The mean positive chloride balance in Phase III associated with a persistent slight mean negative extracellular water balance, accounted for signicant increases in serum chloride concentration in the majority of these patients.

Maximum daily negative sodium balance occurred during Phase II (-43 mEq.) during which time more than twice as much sodium was lost from the chloride space as from the non-chloride space. During Phase III intracellular sodium loss continued at about the same rate $(-12 \mathrm{mEq}$./ day) whereas the rate of extracellular sodium loss decreased appreciably.

Overall mean cumulative potassium balances were : $-44,-233$, and $-288 \mathrm{mEq}$. in progressive phases, respectively. Negative mean daily potassium balance in Phase II (-19.9 mEq.) was approximately twice that in Phases I and III ( -8.8 and $9.3 \mathrm{mEq}$.). The less negative balance in Phase III appears to be related more to increased potassium intake (Table II) than to increasing renal conservation. As could be expected, the change in extracellular balance of potassium was minimal and contributed little to the total balance. Mean total intracellular potassium loss was $285 \mathrm{mEq}$. while total potassium released through cellular catabolism averaged $477 \mathrm{mEq}$. Thus the difference, $192 \mathrm{mEq}$., represented the average amount of potassium taken up by remaining intact cells in excess of nitrogen, or the positive intracellular potassium balance corrected for protein burned. 


\section{Water exchanges}

Mean exogenous water intake given in Table IV (D) exceeded mean sensible water loss by 732 , 328 , and $474 \mathrm{ml}$. per day in successive phases. Daily water of oxidation averaged $309 \mathrm{ml}$. and endogenous preformed water averaged $122 \mathrm{ml}$. with relatively little variation from phase to phase. Insensible water loss averaged $992 \mathrm{ml}$. per day, also with little variation from phase to phase and from patient to patient.

\section{DISCUSSION}

\section{Validity of calculations}

These data have been derived by the balance technique and hence yield information concerning changes in, rather than absolute amounts of, certain body constituents. Measurements of absolute amounts of such constituents as body fat, body water, and certain cations were not feasible, and the techniques were not available for use in these patients. However, assessment of total body composition by determination of whole body specific gravity, or by the dilution of isotopically labelled water requires an assumption of the ratio of water to fat-free solids (16-18). While it is extremely desirable to make such measurements in the study of acute renal failure, as has been done in a small number of these patients (6), changes in body constituents as determined by the balance technique are perhaps more readily done, and should provide much useful and more frequent information over shorter intervals of time.

The estimation of lean body mass at the end of the recovery period from the creatinine excretion must be only an approximation. But error in the absolute magnitude of this fraction of the body, or of its aqueous subdivisions, does not invalidate the changes calculated backwards in time from the balance data; only the percentage values would be affected. The calculation should still give a true picture of changes of the principal body fractions in relation to each other.

The use of the chloride space will not be discussed here in detail; this has been done elsewhere in recent publications $(13,19,20)$. It should be enough to point out that although the chloride space includes the connective tissue subphase (which the inulin space does not) and any other cellular or transcellular phases penetrated by chloride, this space still essentially excludes the major intracellular fluids of the body, such as those of skeletal muscle. In addition, the spurious steady expansion of the inulin space in nephrectomized dogs and in anuric subjects (21) hardly recommends the use of this measurement over that of the chloride space.

The patients when studied during the oliguric phase presented one particular difficulty in the determination of balance data, namely, that the substances ordinarily excreted in urine are retained in the body fluids. Calculation of the decrement of metabolized protein and potassium in a closed system requires measurement or assumption of the fluid volume through which the concentration is raised. This is less accurate than the direct measurement of nitrogen and potassium excreted. In our calculation of the decrement of nitrogen this involved estimation of the volume of total body water. By use of a series of approximations error in assumption can certainly be minimized though not entirely eradicated.

The total amount of fat burned likewise is quantitated indirectly in the absence of direct calorimetry. Such derivation depends upon the assumption of a fixed relationship between total caloric expenditure and the insensible loss of water by vaporization (measured by insensible weight loss). In normal subjects this relationship has been found to vary only by \pm 4 per cent (22); in abnormal subjects the variability is probably greater but this method of derivation seems likely to us to be less subject to error than that employed by Hamburger and Richet (4).

Certainly the quantitative information concerning changes in body constituents during this disease, as derived from balance data, is at best an approximation. However, we believe that these measurements are more complete than any similar observations published to date, and increase our physiologic and therapeutic knowledge of acute renal failure.

The validity of presenting the derived data as mean values and standard deviations deserves some comment. These means were calculated on the basis of individual daily averages in each patient for each phase without weighting the individual averages according to duration of individual studies. However, duplicate calculations weighted 
on the basis of patient-days gave mean values almost identical to those presented.

The division of early and late diuretic phases according to time of maximal diuresis is arbitrary and may not correlate precisely with changing phases of renal recovery. It is further recognized that therapy may determine in part the point of maximal diuresis. This criterion was chosen, however, because it is easily recognized clinically and because it coincides with a change in trend of alteration of body composition in the patients studied.

\section{Catabolic response}

The catabolic response which is of paramount importance in acute renal failure has been discussed by Swan and Merrill in their excellent and comprehensive review of the clinical course of this disease (23). In two cases reported by these authors, daily protein consumption was estimated at 48 and 22 grams, respectively. Hamburger and Richet calculated an average rate of protein catabolism of 75 grams per day in one case, as estimated by urea production (4). These values are in general agreement with those reported here.
Among the factors which may significantly accelerate protein catabolism in acute renal failure are infection, tissue necrosis, and stress of acute illness (24-26). Another possible determinant of catabolic response is the state of nutrition at the onset of oliguria, catabolic rate being probably greater in the previously well-nourished patients than in those previously debilitated by chronic disease (23). While the present series is too small to assess these various factors quantitatively, it is interesting to note that the maximum rate of protein catabolism was observed in Patient B. S., who had the most severe infection in this group, and that the minimum rate was observed in Patient I. $T$., the oldest in the group and the only one who had pre-existing debilitating disease (carcinoma).

The demonstration in uremic animals and in man that endogenous protein consumption can be reduced by high intake of non-protein calories has led to the general acceptance of such dietary therapy in acute renal failure (27-29). Certain theoretical and practical advantages of carbohydrate over fat in this regard have been emphasized $(6,30-32)$. It has also been shown, however, that this protein-sparing effect is inhibited by the presence of extensive tissue damage or severe infec-

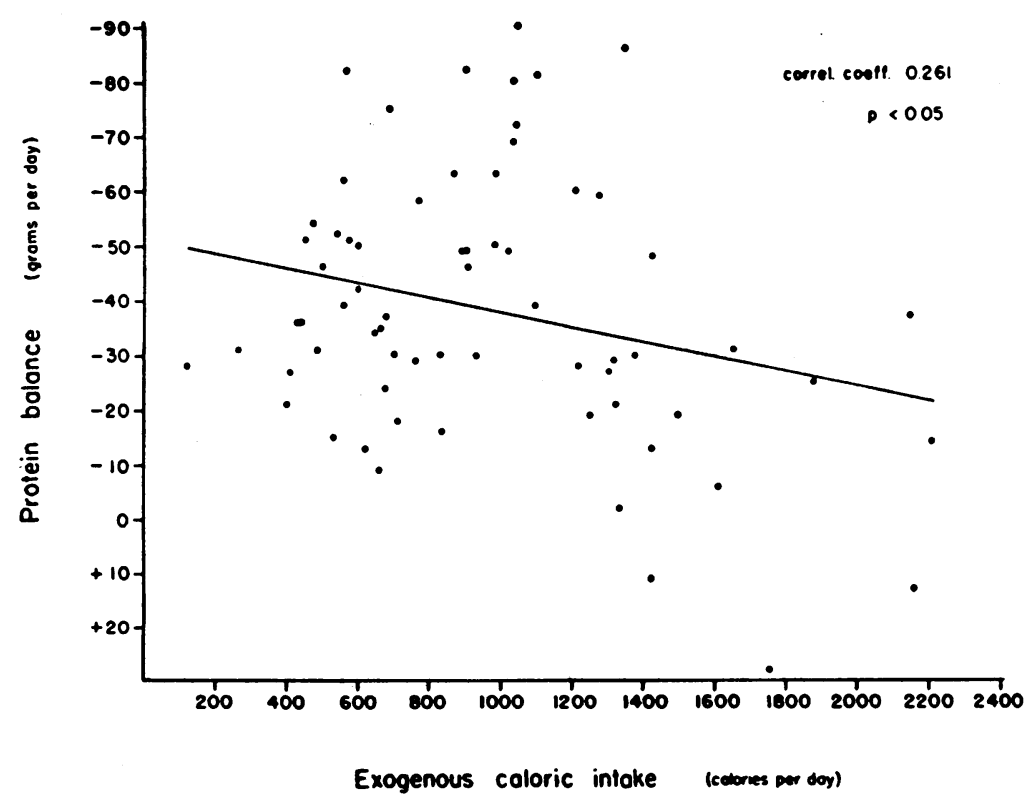

Fig. 3. Relationship Between Protein Balance and Total Exogenous Caloric Intake During Acute Renal Failure

Points represent average daily values in each patient for each unit balance period (1 to 3 days). 


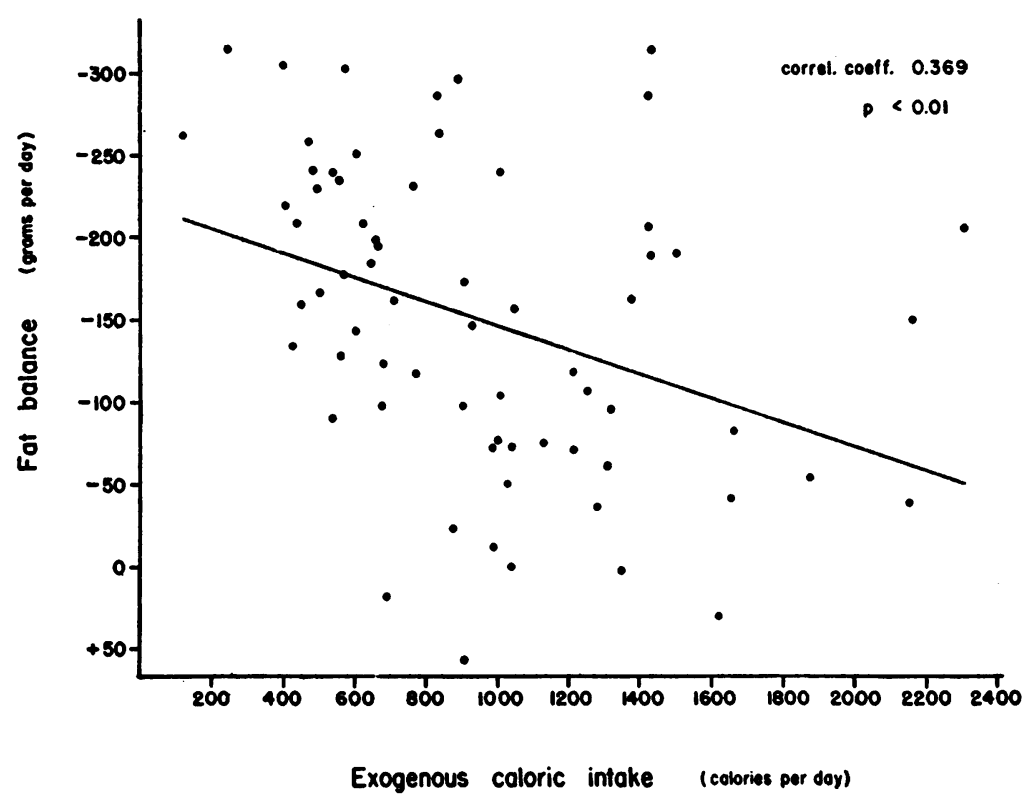

Fig. 4. Relationship Between fat Balance and Total Exogenous Caloric Intake During Acute Renal Failure

Points represent daily average values in each patient for each unit balance period ( 1 to 3 days).

tion (33). An attempt was made in the present series to assess the relationship between protein balance and exogenous caloric intake, largely carbohydrate, in Figure 3, each point representing a daily average for each unit study period (24 to 72 hours) in each patient. While a significant positive correlation is noted, the wide scatter clearly indicates that non-dietary determinants of protein catabolism, such as stress of acute illness, were of major importance in this series. Unfortunately, in most of these patients caloric intake was low initially and was increased during recovery; therefore the apparent correlation may be influenced by improving clinical status and decreasing degrees of stress with time.

The estimated rates of fat catabolism in this series are somewhat lower than those previously derived by Swan and Merrill (23), who subtracted loss of lean body tissue from total weight loss (lean tissue loss estimated from total increase in blood urea nitrogen $\times 28$ ). A significant inverse correlation was observed between daily rate of fat catabolism and exogenous caloric intake, $r=0.369, p<0.01$, in Figure 4 , but again the above-mentioned non-caloric factors must be taken into account. While the mean rate of fat catabolism decreased with decreasing mean stores of body fat in successive phases, no correlation was observed between individual rates of fat catabolism and initial estimated stores of body fat, i.e., the more obese patients in this series did not catabolize fat at a faster rate than did the less obese patients.

\section{Water metabolism}

Aside from influencing the rate of solute retention, the catabolic response in acute renal failure influences total body water through endogenous water of oxidation. As emphasized repeatedly in recent literature, failure to recognize this significant contribution to total body water may lead to iatrogenic over-hydration. Fluid therapy designed to equal total sensible and insensible water loss would theoretically result in an increase in total body water equivalent to the water of oxidation, while fluid replacement designed to maintain constant body weight would theoretically result in an increase in total body water equivalent to water of oxidation and weight of fat burned. Constant total body water would theoretically then be maintained by replacing measured and insensible water loss minus water of oxidation; however, with gradual loss of body solids or lean dry tissue, even such replacement would lead to a gradual 
increasing ratio of water to body solids. Assuming this ratio to be the primary determinant of the state of hydration, optimal water replacement would therefore be designed to approximate total sensible and insensible water losses minus water of oxidation and preformed water released through cellular catabolism ( $\mathrm{SL}+\mathrm{IW}-\mathrm{H}_{2} \mathrm{O}_{\mathrm{ox}}-\mathrm{H}_{2} \mathrm{O}_{\mathrm{pf}}$ ).

In the present series, during the oliguric phase, daily insensible water loss averaged $981 \pm 141 \mathrm{ml}$., a value somewhat higher than those reported in two oliguric patients as determined from water turnover rates using $\mathrm{D}_{2} \mathrm{O}(34)$. The validity of the latter method, however, depends upon maintenance of constant total body water, which was not ascertained in the cases reported. Water of oxidation during oliguria in our patients averaged $303 \pm 30 \mathrm{ml}$. and preformed water averaged $124 \pm$ $75 \mathrm{ml}$. daily. On the basis of these mean values a constant ratio of total body water to body solids would have required approximately $550 \mathrm{ml}$, or $330 \mathrm{ml}$. per sq. meter of body surface area, per day, in excess of measured water loss.

This value serves as a useful guide for fluid replacement in most oliguric adults. It may, of course, have to be revised upward or downward according to individual circumstances, particularly according to the initial state of hydration of the patient. Previous estimates of basic fluid requirements in oliguric patients, based largely on water exchanges in normal subjects under basal conditions, were in close agreement with the value reported here $(6,35,36)$. Neither the latter estimates nor our own, however, support the arbitrary recommendations of daily fluid intake up to 1500 ml. in oliguric patients (37).

\section{Fluid and electrolyte changes}

With regard to fluid and electrolyte changes during the oliguric phase, the data presented are too incomplete and too variable to justify generalizations. The most striking and most consistent changes in fluid volume, however, occurred in the early diuretic phase when a marked reduction in mean total body water, and especially in mean extracellular fluid, was observed. In terms of mean ratios of these compartments to lean body mass, however, (Table V), it is equally significant that the percentage of total body water fell only 1.5 per cent and that the percentage of intracellular fluid actually increased 1.3 per cent, while that of extracellular fluid decreased 2.8 per cent. In this sense, then, one can interpret the predominant volume changes during early diuresis as a relative expansion of intracellular fluid and a relative contraction of extracellular fluid. Since of necessity these studies were not initiated at the onset of oliguria, one can only speculate as to the fluid alterations which occurred during early oliguria. However, if the changes observed during diuresis can be interpreted, at least qualitatively, as compensatory adjustments to previous alterations in the opposite direction, they would be compatible with the supposition of a previous overexpansion of extracellular fluid and relative contraction of intracellular fluid volume during early oliguria. This interpretation would be in keeping with the observations of others $(1-3,6)$ and would gain some support from the fact that adequate fluid restrictions were not imposed in our patients until the time of transfer to our service.

Likewise, the greatest electrolyte changes were noted in Phase II, and consisted of a marked negative balance of sodium, and to a lesser degree, of chloride and potassium. The disproportionately excessive loss of sodium throughout diuresis may be attributable in part to accelerated loss of retained non-chloride anions at a time of impaired renal tubular conservation of cations. Mean intracellular sodium balance remained steadily negative throughout both the early and late diuretic phases, even though extracellular sodium appeared to be conserved during the latter phase. Simultaneously intracellular potassium balance (corrected for cellular catabolism) remained positive to a comparable degree, suggesting a roughly quantitative replacement of potassium for sodium in cells during diuresis. Muscle biopsies were not obtained to confirm a rising $\mathrm{K}-\mathrm{N}$ ratio (corrected for changing NPN) nor were intracellular transfers of magnesium or hydrogen ion calculated.

Again, if one considers these shifts as compensatory in nature, the inference is suggested that during early oliguria potassium may have left cells in exchange for sodium. Support for this supposition would be gained from the experiments which demonstrated the movement of potassium out of cells in acutely uremic dogs with acidosis (38). Similarly, in the balance experiments of Elkinton, Tarail, and Peters (39), potassium left 
L. W. Bluemle, JR., H. P. POTter, AND J. R. ELKinton

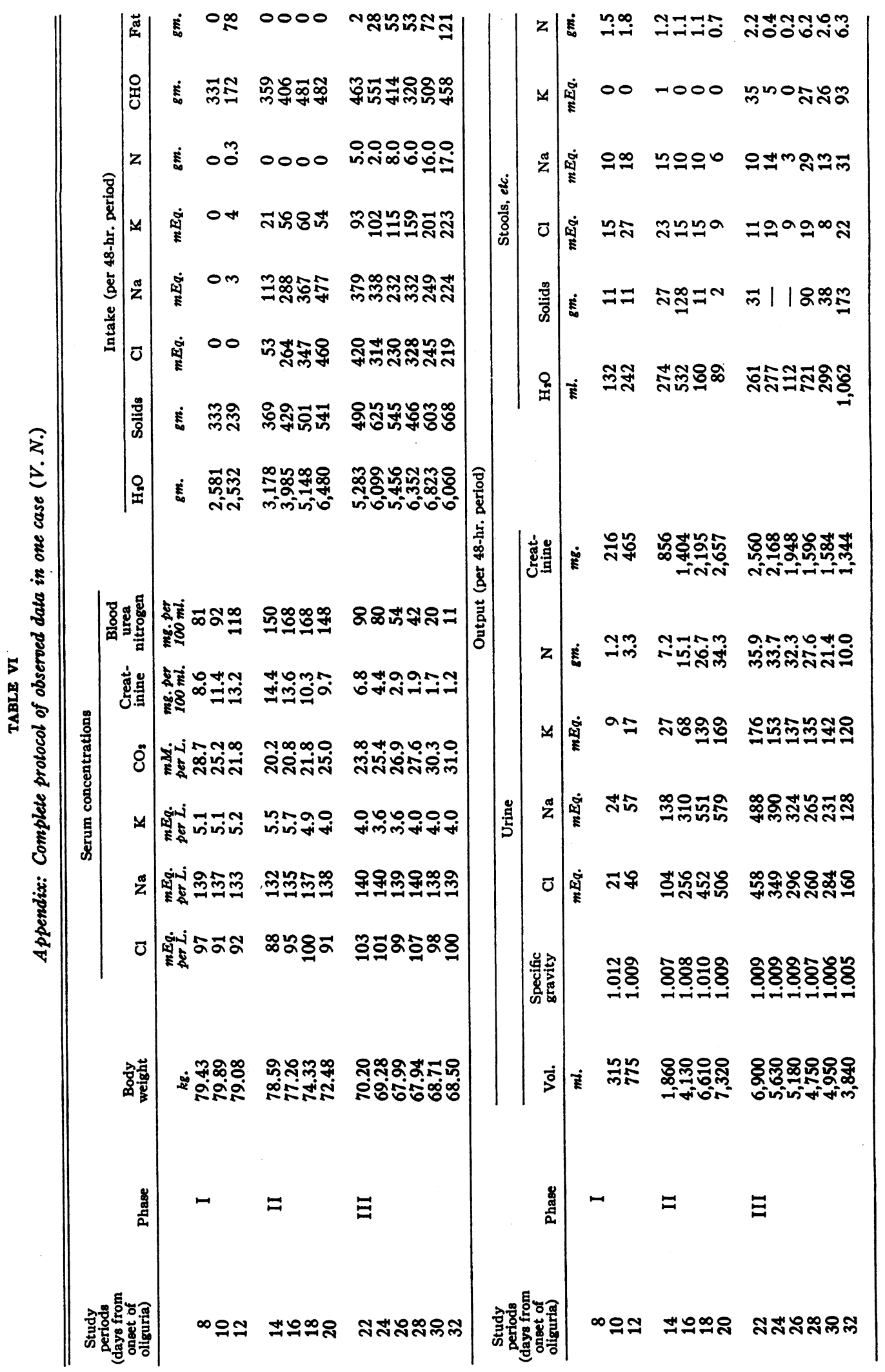


cells in excess of nitrogen in 4 of the 6 oliguric patients studied; however, cellular sodium transfers were variable in these 4 patients.

\section{SUMMARY}

From balance studies carried out in 8 female patients during the oliguric phase, the early diuretic phase, and the late diuretic phase of acute renal failure, mean values were derived regarding the metabolic mixture, changes in body composition, and exchanges of water and electrolytes.

1 . With an average expenditure of 2,500 calories per day, endogenous fat constituted the main source of energy, particularly during oliguria. The mean rate of endogenous protein catabolism remained relatively constant from phase to phase in all patients. The daily rate of endogenous protein catabolism appeared to be only slightly influenced by variations in total exogenous caloric intake, suggesting that non-dietary determinants of catabolic response played a more important role.

2. Mean rates of loss of body fat, water, and solids were roughly proportional to the mean ratios of these compartments to total body weight, except during early diuresis; in this phase a disproportionately great loss of extracellular fluid (chloride space) was observed in all patients.

3. Mean sodium balances were negative in all phases studied, maximally so during early diuresis. Throughout the early and late diuretic phases mean sodium balance remained significantly more negative than mean chloride balance. This was attributable in part to defective tubular conservation of cations at a time of accelerated excretion of retained non-chloride anions. Diuresis was also attended by a mean intracellular shift of potassium in exchange for sodium in approximately equal amounts.

4. By subtracting mean values for water of oxidation and preformed water released through cellular catabolism from mean values of insensible water loss, an estimate was made of the amount of exogenous water required in excess of measured water loss, to maintain a constant ratio of total body water to total body solids. This value averaged $550 \mathrm{ml}$. per day or $330 \mathrm{ml}$. per sq. meter of body surface area per day, during oliguria. The therapeutic implications of this finding were discussed.

\section{ACKNOWLEDGMENT}

We are indebted to Mrs. Lidia Kozachkov, Mrs. Katherine Wisnevski, and Mrs. Dolores Bluemle of the Chemical Section of the Department of Medicine, and to Dr. John Reinhold, Chief of the Chemistry Division of the Pepper Laboratory, for chemical analyses; to Mrs. Cynthia Henderson, Miss Helen Merton, and Mrs. Patricia McCreary and the nursing staff on the Metabolic Unit; and to Mrs. Marie Bunting, Miss Mary Demyan, and Miss Nancy Sweeney for dietetic services.

\section{REFERENCES}

1. Sirota, J. H., and Kroop, I., Water and electrolyte disturbances in acute renal insufficiency. Federation Proc., 1951, 10, 126.

2. Schwartz, R., Tomsovic, E. J., and Schwartz, I. L., Hyperpotassemia and body water distribution in an anuric child. Pediatrics, 1951, 7, 516.

3. Iseri, L. T., Batchelor, T. M., Boyle, A. J., and Myers, G. B., Studies of fluid, electrolyte, and nitrogen balance in acute renal insufficiency. Arch. Int. Med., 1952, 89, 188.

4. Hamburger, J., and Richet, G., Sur un phénomène de libération d'eau endogène observé notamment au cours de certaines anuries. Bull. et mém. Soc. méd. d hôp. de Paris, 1952, 68, 368.

5. Hamburger, J., and Mathé, G., Fluid balance in anuria. Ciba Foundation Symposium on The Kidney, Boston, Little, Brown and Co., 1954, p. 288.

6. Merrill, J. P., The Treatment of Renal Failure. New York, Grune and Stratton, 1955.

7. Bluemle, L. W., Jr., and Elkinton, J. R., A stretcherscale for the accurate weighing of bedridden patients. J. Lab. \& Clin. Med., 1953, 41, 300.

8. Elkinton, J. R., Squires, R. D., and Crosley, A. P., $\mathrm{Jr}$., Intracellular cation exchanges in metabolic alkalosis. J. Clin. Invest., 1951, 30, 369.

9. Lavietes, P. H., The metabolic measurement of the water exchange. J. Clin. Invest., 1935, 14, 57.

10. Peters, J. P., Kydd, D. M., and Lavietes, P. H., A note on the calculation of water exchange. J. Clin. Invest., 1933, 12, 689.

11. Miller, A. T., Jr., and Blyth, C. S., Estimation of lean body mass and body fat from basal oxygen consumption and creatinine excretion. J. Applied Physiol., 1952, 5, 73.

12. Elkinton, J. R., and Winkler, A. W., Transfers of intracellular potassium in experimental dehydration. J. Clin. Invest., 1944, 23, 93.

13. Elkinton, J. R., and Danowski, T. S., The Body Fluids: Basic Physiology and Practical Therapeutics. Baltimore, The Williams and Wilkins Co., 1955.

14. Rowntree, L. G., The water balance of the body. Physiol. Rev., 1922, 2, 116.

15. DuBois, D., and DuBois, E. F., Clinical calorimetry. V. The measurement of the surface area of man. Arch. Int. Med., 1915, 15, 868. 
16. Behnke, A. R., Jr., Feen, B. G., and Welham, W. C., The specific gravity of healthy men. Body weight $\div$ volume as an index of obesity. J.A.M.A., 1942, 118, 495.

17. Pace, N., and Rathbun, E. N., Studies on body composition. III. The body water and chemically combined nitrogen content in relation to fat content. J. Biol. Chem., 1945, 158, 685.

18. Edelman, I. S., Haley, H. B., Schloerb, P. R., Sheldon, D. B., Friis-Hansen, B. J., Stoll, G., and Moore, F. D., Further observations on total body water. I. Normal values throughout the life span. Surg., Gynec. \& Obst., 1952, 95, 1.

19. Singer, R. B., Clark, J. K., Barker, E. S., Crosley, A. P., Jr., and Elkinton, J. R., The acute effects in man of rapid intravenous infusion of hypertonic sodium bicarbonate solution. I. Changes in acidbase balance and distribution of the excess buffer base. Medicine, 1955, 34, 51.

20. Elkinton, J. R., Singer, R. B., Barker, E. S., and Clark, J. K., Effects in man of acute experimental respiratory alkalosis and acidosis on ionic transfers in the total body fluids. J. Clin. Invest., 1955, 34, 1671.

21. Finkenstaedt, J. T., O'Meara, M. P., and Merrill, J. P., Observations on the volume of distribution of inulin in anuric subjects. J. Clin. Invest., 1953, 32, 209.

22. Newburgh, L. H., and Johnston, M. W., The insensible loss of water. Physiol. Rev., 1942, 22, 1.

23. Swann, R. C., and Merrill, J. P., The clinical course of acute renal failure. Medicine, 1953, 32, 215.

24. Grossman, C. M., Sappington, T. S., Burrows, B. A., Lavietes, P. H., and Peters, J. P., Nitrogen metabolism in acute infections. J. Clin. Invest., 1945, 24, 523.

25. Bywaters, E. G. L., Ischaemic muscle necrosis ("crush syndrome"). Brit. M. Bull., 1945, 3, 107.

26. Teschan, P. E., Post, R. S., Smith, L. H., Jr., Abernathy, R. S., Davis, J. H., Gray, D. M., Howard, J. M., Johnson, K. E., Klopp, E., Mundy, R. L., O’Meara, M. P., and Rush, B. F., Jr., Post-traumatic renal insufficiency in military casualties. I.
Clinical characteristics. Am. J. Med., 1955, 18, 172.

27. Borst, J. G. G., Protein katabolism in uraemia. Effects of protein-free diet, infections, and bloodtransfusions. Lancet, 1948, 1, 824.

28. Bull, G. M., Joekes, A. M., and Lowe, K. G., Conservative treatment of anuric uraemia. Lancet, 1949, 2, 229.

29. Kolff, W. J., Forced high caloric, low protein diet and the treatment of uremia. Am. J. Med., 1952, $12,667$.

30. Munro, H. N., Carbohydrate and fat as factors in protein utilization and metabolism. Physiol. Rev., 1951, 31, 449.

31. Engel, F. L., Further observations on the role of the adrenal cortex in the metabolism of amino acids. Endocrinology, 1951, 49, 538.

32. Bull, G. M., Acute renal failure. Transactions of the Fifth Conference on Renal Function, Bradley, S. E., Ed. New York, The Josiah Macy, Jr., Foundation, 1953, p. 114.

33. Masson, G., Corcoran, A. C., and Page, I. H., Dietary and hormonal influences in experimental uremia. J. Lab. \& Clin. Med., 1949, 34, 925.

34. Haley, H. B., Edelman, I. S., and Moore, F. D., The turnover rate of body water in the human. $S$. Forum (1951) pp. 595-601, 1952.

35. Strauss, M. B., Therapeutic considerations in acute renal impairment. Bull. New England M. Center, 1949, 11, 247.

36. Strauss, M. B., and Raisz, L. G., Clinical Management of Renal Failure. Springfield, Charles C Thomas, 1956.

37. Murphy, F. D., Acute toxic nephrosis. Postgrad. Med., 1952, 12, 191.

38. Keating, R. E., Weichselbaum, T. E., Alanis, M., Margraf, H. W., and Elman, R., The movement of potassium during experimental acidosis and alkalosis in the nephrectomized dog. Surg., Gynec. \& Obst., 1953, 96, 323.

39. Elkinton, J. R., Tarail, R., and Peters, J. P., Transfers of potassium in renal insufficiency. $\mathrm{J}$. Clin. Invest., 1949, 28, 378. 